Review research paper

\title{
USING LITERARY TEXTS IN NORWEGIAN LANGUAGE TEACHING
}

\author{
Danica Piršl ${ }^{1}$, Tea Piršl ${ }^{2}$ \\ University of Niš, Faculty of Sport and Physical Education, Niš, Serbia \\ University of Niš, Faculty of Philosophy, Niš, Serbia
}

\begin{abstract}
The use of literary texts in teaching language has varied from the strict focus on translation and essential grammar and vocabulary lists derived from the text to the more creative uses like acting, writing and debating. Nowadays, communicative language approach prevails in most classrooms and insists on immersing students into both the target language and culture. In this paper, the author argues that to accomplish this, one can use literary texts in a number of ways and help the students learn, practice and master various language skills, while at the same time relating the texts to the students' interests, goals and lived experiences and help them relate to the society whose language they are learning. Literature is presented as a great source of authentic material that can contribute to students' language enrichment and cultural awareness. According to the data obtained from the research conducted for the purpose of this paper, students learning the Norwegian language by extensive use of literature reported better understanding of the target culture, raised awareness of the different cultural patterns and improved language skills. The pedagogical implications of the research are that more authentic literary texts should be used in language classroom to boost successful language acquisition.
\end{abstract}

Key words: literature, language learning, cultural awareness, Norwegian literature, Norwegian language

\section{INTRODUCTION}

Literature has always had an important place in language teaching, from the grammartranslation method to the communicative language teaching in use today. The use of literary texts has varied from the strict focus on translation and essential grammar and vocabulary lists derived from the text to the more creative uses like acting, writing and debating. Cook notes that during the reign of the translation method "success was measured in terms of the accurate use of grammar and vocabulary rather than effective communication" (Cook, 2003: 32) and that "using the language meant written translation" (Cook, 2003:33). There was no emphasis on fluency, but rather on the fact that one could correctly translate given texts, however abstract and removed from real life experiences they might have been. In language teaching today, however, the focus has been shifted

Submitted January $30^{\text {th }}, 2021$, accepted for publication March 20 2021

Corresponding author: Danica Piršl. Faculty of Sport, University of Niš, Čarnojevića 10a, 18000 Niš, Serbia E-mail: danicapirsl@gmail.com 
from successful translation to successful communication and what is highlighted now is "the ability to do things with the language, appropriately, fluently, and effectively" (Cook, 2003: 36). Stressing the relevance of the classroom tasks to the students' goals, as a part of CLT, has extensively featured in classrooms around the world, as well as the idea that "language is best handled all at once, as it would be in the real world" (Cook, 2003:37).

In this paper, the author argues that to teach students how to handle language as it would be in the real world, one can use literary texts in a number of ways and help the students learn, practice and master various language skills, while at the same time relating the texts to the students' interests, goals and lived experiences. Literature is presented as a great source of authentic material that can contribute to students' language enrichment and cultural awareness. Thus, the paper will present the author's experience in teaching Norwegian by using Ellingsen and MacDonald's book Stein på stein, which offers a variety of literary texts suitable for diverse type of activities. The student's book, intended for the intermediate (B1) level, is accompanied by the teacher's book that offers a wide range of possible tasks that the teacher can implement in her or his classroom. The author will show how she used the exemplary texts in her classroom when helping the students improve their reading, writing, listening and speaking skills. The texts featuring in the student's book relate directly to the themes and topics of the units. The texts are mostly by Norwegian authors, thus providing the students with access to Norwegian literature while being a useful tool that provides the arguments for discussion needed in the specific unit. Lastly, the opinions, criticism and suggestions of the students who have completed the B1 course, regarding the use and importance of the texts given in the student's book, will be given and briefly discussed. In the conclusion, all the obtained results will be used to highlight the pedagogical implications of the practice of including literature in the language learning process.

\section{REASONS FOR USING LITERARY TEXTS IN LANGUAGE TEACHING}

It is an undisputed fact that literature cannot exist without language. Literature is created by language and is in itself an example of language use. For centuries, it has been used to aid the acquisition of language, therefore Brumfit and Carter rightfully call it "an ally of language" (Brumfit and Carter, 1986:5). According to Lenore, just the use of drama in teaching promotes language development, develops critical thinking skills, heightens effective listening skills, increases empathy and awareness of others, strengthens comprehension and learning retention by involving the senses as an integral part of the learning process and reinforces positive self-concept (Lenore, 1993: 43-47). Collie and Slater also assert that including literature in language teaching can be extremely beneficial and to support their claim, they state four reasons to include it in the classroom. They claim that literary texts are "valuable authentic material" and that they can serve the purpose of "cultural enrichment" and "language enrichment" while also prompting the student's "personal involvement" (Collie and Slater, 1990:5). The reason why literature is seen as a "valuable authentic material" is, according to Collie and Slater, because it "offers a bountiful and extremely varied body of written material which is 'important' in the sense that it says something about fundamental human issues, which is enduring rather than ephemeral. Its relevance moves with the passing of time, but seldom disappears completely" (Collie and Slater, 1990:6). 
The fact that many literary critics have been dissecting the same works of Shakespeare, for example, and have always found new meaning and related it to the time they lived in, proves that literature is always relevant and important. It is also "authentic" in the sense that it was not written with the idea that it would be used for language teaching but is rather an authentic expression of the author:

"In reading literary texts, students have also to cope with language intended for native speakers and thus they gain additional familiarity with many different linguistic uses, forms and conventions of the written mode: with irony, exposition, argument, narration, etc. And, although it may not be confined within a specific social network in the same way that a bus ticket or an advertisement might be, literature can nonetheless incorporate a great deal of cultural information" (Collie and Slater, 1990:6).

As far as the "cultural enrichment" component is concerned, the authors mention that it is important for the students to somehow experience culture and while those experiences are usually not readily available, they can be compensated by focusing on certain literary texts. Literature is full of colorful characters that come from different backgrounds and exhibit behavior that can be used to describe and understand certain customs, social codes and norms typical for the country they come from, and help the student gain insight into the culture whose language they are studying (Collie and Slater, 1990:6). Kitao asserts that having insight into the culture of the target language can account for language learning motivation and that after learning more about the culture of the language they were studying, the students "showed an increased interest in studying foreign languages and foreign cultures" (Kitao, 2000:17). Implementing the cultural context into foreign language teaching can be said to play an important role since, according to Kitao, "students have difficulty relating to the people of another culture without knowing anything about them" (Kitao, 2000:17).

Teachers worldwide advise their students to read more in order to improve their vocabulary and master the language faster. Collie and Slater advocate for the same practice by including "language enrichment" as their third reason for using literature in teaching. Students get acquainted with a variety of lexical and syntactic items when reading. They learn about syntax, various different ways of connecting ideas and using sentence structures which later can improve their own writing and speaking skills (Collie and Slater, 1990:7). Povey argues that "literature will increase all language skills because literature will extend linguistic knowledge by giving evidence of extensive and subtle vocabulary usage, and complex and exact syntax" (Povey, 1967:43). The texts can equip students with new idioms and expressions that can aid them in better expressing and conveying meaning. The authors claim that "literary language is not always that of daily communication, as we have mentioned, but it is special in its way. It is heightened: sometimes elaborate, sometimes marvelously simple yet, somehow, absolutely 'right'"(Collie and Slater, 1990:7).

Finally, the personal involvement fostered by the literary texts used in the classroom can improve student's learning experience and language acquisition because the student "becomes involved in the text and enthusiastic to find out what happens as events unfold via the climax; he feels close to certain characters and shares their emotional responses" (Hişmanoğlu, 2005:55). This can have beneficial effects upon the whole language learning process.

Hişmanoğlu mentions that, apart from all the reasons mentioned, using literature in language teaching is important because literature possesses sociolinguistic richness. It provides students with language varieties and exposes them to different dialects, sociolects, jargon, etc., thus developing the student's own sociolinguistic competence in the target 
language (Hişmanoğlu, 2005:56). By acquainting the students with language varieties, literary texts help them adapt and better understand the culture of the language they are learning and can help them develop tolerance and acceptance of the existence of different forms of the standard language.

\section{WAYS OF USING LITERARY TEXTS IN CLASSROOM}

Carter and Long propose three approaches to teaching literature: the language model, cultural model and the personal growth model (Carter and Long, 1991:2). The language model focuses on the way language is used in literary texts and draws the students' attention to grammar, lexical and discourse categories. Literature is seen as a medium for teaching specific vocabulary and grammatical structures. Bobkina and Dominguez write that this model considers literary texts "as a wide source of contextualized linguistic features that can be systematically implemented through a wide range of activities" while the literary quality of the texts remains ignored (Bobkina and Dominguez, 2014:253).

On the other hand, the cultural model represents all the possibilities literature brings into teaching, regarding cultural awareness and appreciation of different cultures. Padueran calls this approach "transdisciplinary" because it does not bring into focus "mere language acquisition, but also the knowledge of a country's culture and ideologies" and encourages students to "go beyond the lexis to other components of a nation" (Padueran, 2015:196). This model demands that students explore, engage with and interpret the given text in regards to its social, literary, historical and political time and context.

The third approach, the personal growth model, tries to create a hybrid model out of the two models already mentioned. Carter and Lang state that it prioritizes personal experience "as a means to engage students in the reading process" while their interaction with the texts serves to "enhance their personal development and language awareness" (Carter and Lang, 1991:3). This model relies on the students expressing their own beliefs and opinions while engaging with the literary texts. Their critical opinion is valued and the connections between the texts and the students' real-life experiences are encouraged.

In this paper, the author advocates for the combined method as it will be shown in the following segments. The student's book examined in this paper contains preselected literary texts and the activities that accompany them. They vary from grammar exercises to debates about current political topics. The author will give examples and explain how the texts were used in her classroom in separate segments, each relating to a specific language skill that was targeted by the activities.

\subsection{Reading}

All of the literary texts in Stein på stein can be used for different reading exercises. First and foremost, they can all be used to practice reading. Even though the students are at an intermediate level, new words sometimes cause confusion because students are not sure about the word's correct pronunciation. Therefore, reading the texts can serve as a reminder of pronunciation rules. In the second unit of the book, the students read the excerpt I sjasmines tid (In the time of jasmine) from Tage Danielsson's book Tage Danielsson: Bok. The pronunciation of the words like "vidunderlig" and "barnslig" tend to confuse the students since the rule of never pronouncing the letter " $d$ " in combination with " $n$ " is constantly overlooked as well as the rule of reading "sl" as "fl". 
The book contains questions regarding every text and they relate mostly to the topic of the text, the persons depicted in it and the themes. The questions encourage students to think and give their answers in Norwegian thus allowing them to practice sentence structures and vocabulary. What students find even more useful are reading comprehension exercises that mirror the exercises that are featured in official Norwegian language tests like "Norskprøve" and "Bergenstest". The tests bear resemblance to TOEFL and IELTS tests and the certificates are usually required from the foreign workers coming to Norway. By simulating the reading comprehension part of the test, the students can prepare and gain more confidence for the eventual participation in the official testing. The same simulation exercise can be done when testing and practicing other language skills, too.

Keshavarazi reminds that "literature provides learners with texts which are above the level of their production/understanding. In fact, literature helps students improve their reading comprehension of the language. They give chance to the students as well as teachers to set various forms of questions based on their contents" (Keshavarazi, 2012:556). By using the text given in the fourth unit of the student's book, the author of this paper has done exactly the same thing. The students can read and focus on the excerpt from Erlend Loe's book Naiv.Super (Nä̈ve. Super) and then answer ambiguous questions about various parts of the text and explain some unfamiliar words. Since it is unrealistic to expect to be familiar with all of the words in the texts that would be given in "Norskprøve" exam, this proves to be an excellent opportunity to practice and recreate the atmosphere of the real reading comprehension test. As a modern writer whose style is ripe with irony, humor and exaggeration, Loe's texts present a great source of modern and creative use of language. His choice of words and his syntax can make the test challenging and didactic.

A lot of other strategies that Ritlyová mentions can be applied: skimming, scanning, predicting, intensive and extensive reading (Ritlyová, 2014:97). The students can match the titles with the paragraphs, extract specific information that is required of them, speculate about the development of the text and focus on finding certain lexical and grammatical units.

Naturally, these texts also serve to introduce new vocabulary and certain grammatical points. Some of the vocabulary can be suggested by the students, as was, for example, the case with the text I sjasmines tid. The students wanted to learn more about flower vocabulary and were presented with the list of flowers with their Serbian equivalent:
(en) blomst - flower
(en/ei) rose - rose
(en) tusenfryd - daisy
(en) løvetann - dandelion
(en) ringblomst - marigold
(en) lavendel - lavender
(en) fiol - violet
(en) påskelilje - daffodil

The same text can be used for the activity concerning the perfective forms of verbs. The students can try to find the verb forms, underline them and provide the infinitive and imperfective forms.

\subsection{Writing}

After having read the texts, students usually get written assignments whether as homework or as an in-class activity. The questions that appear in the book relating to the text can sometimes be used as an essay topic. The activities concerning writing are numerous. The students could write a short dialogue between the characters from the text, or write an imaginary interview with a character, write an original story, compose a new ending, insert 
their own character into the text, pretend to be a character from the story and write a dairy for one day, give their own opinion about the text or the characters, etc.

The third unit features a poem by the Norwegian poetess Inger Hagerup called Jeg vil bygge meg en gård (I will build myself a farm). The poetess writes about building a farm and about her daily activities there. This poem can serve as a good basis for the written assignment about the dream house and dream job that the students wish to have. The students can write about their future jobs in Norway and what activities those jobs would entail. Since a lot of the students in the author's classroom were doctors and nurses, this activity prompted their questions about specific vocabulary related to their occupations. They also had to research on their own and had come up with some of the following results:
(en/ei) mental helse - mental health
(en) medisin - medicine
(en) blodforgiftning - sepsis
(en) diagnose - diagnosis
(en) spiseforstyrrelse - eating disorder
(en) lungebetennelse - pneumonia

The tenth unit gives the students insight into the Norwegian folklore and provides a good basis for comparative writing and gaining insight into the Norwegian fairytales, mythology and superstitious belief. Bottino claims that the students have to have the ability to "identify with the experiences, thoughts and situations in the text" and to be able to "enjoy it by relating it to what they themselves know about themselves and the world" (Bottino, 1999:213). She also states that "a learner who is involved with the text" will want to work on his or her language skills and will use the text as stimulus for further advancement of his knowledge of the language (Bottino, 1999:213).

The students read a fairytale called Askeladden som kappåt med trollet (Askeladden who ate with the troll). From the beginning, the students can draw parallels with their own culture by comparing the character of Askeladden with the Serbian folk hero Prince Marko since both are the heroes of many folktales. In Serbian folktales, Prince Marko encounters fairies, whereas Askeladden encounters trolls. They both rely on cunning and trickery and are depicted as mortal men.

In this fairytale, Askeladden outsmarts the troll and saves himself and his family from ruin. One of the tasks that the students are assigned is to retell the fairytale and write about what they would do if they were in Askeladden's place. The fairytale provides an opportunity to talk about Norwegian mythology and Scandinavian folklore. After the discussion in class, the students have to write an assignment on the topic covered and they have to answer the following questions: "Why do so many fairytales feature trolls?" "How does Norwegian landscape tie into this?" "Why hasn't this particular mythological being ever appeared in Serbian folklore?" "How do the mythologies of both cultures differ?", etc. After the discussion, the students are advised to watch certain movies, read other relevant texts and listen to music and podcasts.

\subsection{Listening}

Stein på stein is a book that comes with audio recordings of almost all the texts that can be found inside. The audio is recorded by native Norwegian speakers and can offer insight into the vast world of Norwegian dialects. One of the texts is read by Erlend Loe himself, so the students have the opportunity to hear the writer read his own work in the target language. Brown writes that: 
"whether students are listening individually to a recorded poem to hear the uses of figurative language or the whole class is listening as their teacher reads a particularly dramatic chapter from the book everyone is assigned, students will hear and experience the sound of intertwining of words and their power to convey meaning and images and ideas and hopes. A shared listening activity provides both teachers and students with an experience that is both vital and immediate". (Brown, 2001:14)

However, when dealing with developing this particular language skill, passive listening without tasks will not yield significant results. As Ritlyová observes in her paper - "listening is an active activity" and states that any listening activity will be successful only if "the students are given a particular task and if they listen to find specific information" (Ritlyová,2014:98). As with both reading and writing, listening activities abound.

The teacher's book offers more texts that can be used besides the ones in the student's book. Another fairytale is given, Askeladden som hadde gulleplene (Askeladden who had gold apples), that can be used in various listening exercises. The students can fill in the gaps, answer questions, try to predict the outcome after having listened to only half of the story, describe the character's feelings and motivation based on his or her tone of voice and words, answer true/false questions or do multiple choice, guess the meaning of new vocabulary, point out unfamiliar idioms, etc. Listening to the native speakers can also stimulate the learner's desire to approximate their speaking abilities to those of the native speakers "by adhering to the principles of rhythm, rhyme, and intonation" (Shazu, 2014:32).

In the fourteenth unit, students can listen to Henrik Ibsen's Et dukkehjem (A Doll's House). The language of the play is somewhat different from the language of the classroom that the students are used to and that can help the teacher open a discussion about the way Norwegian language has changed throughout history and the implications of that change. This text can also lead, for example, to a compilation of Norwegian phrasal verbs and expressions with body parts. When students hear Nora say "bare fra hånden og i munnen" they recognize the words "hånd" and "munn" as "hand" and "mouth" respectively, but do not understand what the expression as a whole means. The teacher can then provide the students with a list of frequent expressions that contain words relating to body parts.

Brown states that "listening to books helps students to understand the development and evolution of characters and the interrelationships among them" and talks about her own classroom experience where her students had indicated that they enjoyed the assigned book more when hearing it on tape and that they loved experiencing the characters' unique voices and sharing their emotions (Brown, 2001:16). Personal involvement like this can enhance language acquisition and help the student feel more relaxed by creating a more carefree atmosphere in the classroom and therefore enable her or him to better focus on developing the language skills needed.

\subsection{Speaking}

Literary texts are very convenient for speaking activities and the teacher can exploit them to improve the students' communication skills. Activities like role play, improvisation, retelling, debate, oral comprehension check questions, presentations, etc. are all applicable here. The activities serve to improve speaking abilities and to maintain students' interests and involvements at the same time (Phat, 2013:676). Developing this language skill is what students focus on most, since the reason they are studying the language is to be able to use it in daily life and to be understood. This interest ties neatly with the goal of the communicative 
language approach that is in use in most classrooms today. Ur says that "of all the four skills, speaking seems intuitively the most important. People who know a language are referred to as "speakers" of that language, as if speaking included all other kinds of knowing, and many if not most foreign learners are primarily interested in learning to speak" (Ur, 1991:120).

The text Et dukkehjem by Ibsen can serve well as the starting point for many of the already named speaking activities. Since it deals with the suffocative environment in which women lived in the 19th century and with criticism of the marriage institution it can be used in classroom as the basis for the debate about women's rights and male-female relationships. The students learn about the fact that the play was considered very controversial and that Ibsen had to change the ending for his audience in Germany as it was unimaginable for a woman to just leave her husband at that time. Ellingsen and Macdonald give extra texts in the teacher's book that can be given to students and also some questions that could help with the debate. The students split into two groups and then follow the rules of debating previously given to them by the teacher. The debate provides them with the opportunity to practice speaking but also to use the vocabulary they learned in the unit. More complex sentence structures have to be used in order to ground the arguments, so the students have to start using subordinating conjunctions, relative clauses and complex tenses. In any debate exercise students have the chance to share their views with their classmates and present their arguments confidently while the teacher has the opportunity to correct mistakes and assess students' overall communicative and linguistic competence.

The introduction of Henrik Ibsen and his work can be used by the teacher as a convenient occasion for learning more about the capital of Norway. By using the map of Oslo and Google Maps the students are encouraged to imagine walking down the main street of the city, Karl Johans gate, and reaching the National Theatre where they can see the statue of Ibsen. They practice giving and asking for instructions and can experience the way language figures in everyday life.

The ninth unit dealing with immigration and emigration introduces two literary texts that describe the lives of Norwegian immigrants in the USA and Pakistanis that emigrated to Norway. In the excerpt from the Norwegian - American author Ole Edvart Rølvaag's book Peder Seier students read about a frustrated Norwegian mother trying to stop her son's assimilation into American society. The learners could state their own opinions about the situation and imagine themselves and their own reactions in the given scene. They can be encouraged to enact it and provide arguments for their opinions. This particular topic can be of interest to the students because a lot of them anticipate moving to a foreign country and the activity can give them the chance to experience it through another person's eyes.

The other text by Norwegian-Pakistani writer Khalid Hussain deals with a similar topic. However, this time the author concerns himself with the potential loss of faith in the face of assimilations as opposed to the loss of language from the previous text. The dialogue from his novel Pakkis depicts a conversation between a father and a son concerning Islam and the ways in which the son has been neglecting his faith in order to be more like his Norwegian friends. The same activities already mentioned can be applied to this text. Both texts can be dramatized and acted out in various ways. The students can come up with the second part of the conversation or insert new characters or even themselves. Phat writes that role play can be a "riveting activity in which the students can develop the story in their own way, write their own dialog and bring their own props. This makes the classroom atmosphere become stimulating for all of the students and enhances the students' appreciations of a literary work" (Phat, 2013:676). 
By doing all these activities students become active participants in the classroom rather than just passive listeners and they develop affinities for the written word and become aware of all the opportunities it offers.

\section{STUdENTS’ ATtITUdES ON THE USE OF LITERARY TEXTS WITHIN A LANGUAGE COURSE}

The participants in this study were 15 students that had successfully completed the intermediate Norwegian language course and were using the book Stein på stein. They were all new to the Norwegian language and culture and were studying the language with the hopes of moving to and working in Norway. A set of questions (some open-ended and some yes/no questions) was used to collect data from the participants. The questions used focused on the following themes: language skills, cultural awareness, attitudes on the use of literary texts in teaching and critical assessment and suggestion of the activities. The overall scores of all participants are calculated and presented on the following pages.

Students' responses to the question of whether the texts used in the course contributed to their language acquisition showed that almost all students, 14 out of 15 (93.3\%) answered positively ("Yes"), showing their belief in the positive effect of the use of aforementioned texts on their language learning (Table 1

Table 1 Literary texts' contribution to language learning

\begin{tabular}{|l|c|c|}
\hline Response & Frequency & Percent \\
\hline Yes & 14 & 93.3 \\
\hline No & 1 & 6.6 \\
\hline Total & 15 & 100.0 \\
\hline
\end{tabular}

When it comes to the improvement of the language skills, the use of texts influenced students' reading and writing skills most. This is probably mainly due to the frequent homework reading and writing assignments and the lack of time for the focus on listening and speaking practice (Table 2)

Table 2 Language skill improvement

\begin{tabular}{|l|c|c|}
\hline Response & Frequency & Percent \\
\hline Reading & 6 & 40.0 \\
\hline Writing & 4 & 26.6 \\
\hline Listening & 2 & 13.3 \\
\hline Speaking & 3 & 20.0 \\
\hline Total & 15 & 100.0 \\
\hline
\end{tabular}

The aim of understanding the Norwegian culture and relating to the people was achieved. Table 3 shows that $80 \%$ of the students felt that they understood the Norwegians and their culture better after having completed the course. 
Table 3 Raising cultural awareness

\begin{tabular}{|l|c|c|}
\hline Results & Frequency & Percent \\
\hline Yes & 12 & 80 \\
\hline No & 3 & 20 \\
\hline Total & 15 & 100 \\
\hline
\end{tabular}

The positive effect of the use of literature in the course can be seen from the following statistics: $66.6 \%$ of the students felt motivated to research the Norwegian culture more, thus enhancing their language acquisition by taking up more extensive reading of Norwegian authors. The students also reported greater interest in Norwegian cinema, theatre, music, architecture and linguistics.

Table 4 Motivation for further research

\begin{tabular}{|l|c|c|}
\hline Results & Frequency & Percent \\
\hline Yes & 10 & 66,6 \\
\hline No & 5 & 33,3 \\
\hline Total & 15 & 100,0 \\
\hline
\end{tabular}

The students were satisfied with the way the activities in classroom were conducted but they singled out dramatic monologues, essay writing, debate, presentation, role play and writing of the alternative endings for the texts they had read. One student explained that she liked role play "since it somehow dramatized the text and brought it to life". Another one explained that debating in class forced her to "have the thoughts translated into Norwegian" while the other considered the activity "a good practice for formal negotiations and arguments in real life, like working conditions and salary".

When asked to explain what they would do differently when dealing with literary texts and the way they were used in the classroom the students suggested various activities. One student wrote the following: "I would give the students freedom to choose the works they want to read and discuss. I would also organize a reading club or a literary club, where the students would have the opportunity to meet, look at the texts from different points of view and exchange their ideas." Other students suggested performing a simulation of a trial like they had done in high school. Learning poems and excerpts by heart and performing them in front of the class were also some of the suggestions. Making a short movie based on one of the texts or poems with a phone camera, bringing puppets and acting out a dialogue from the text and making power point presentations on the authors and texts were also some of the activities named.

\section{CONCLUSION}

This paper set out to argue for the inclusion of literary texts in the Norwegian language learning and to show its impact on the students already exposed to it. Babaee and Yahya write that "literary texts are reliable sources of linguistic inputs and can help the students practice the four skills - speaking, listening, reading and writing" and that literature is more "representational instead of referential" (Babaee and Yahya, 2014:84). Literature involves the students, their feelings, experiences and perceptions of the world. 
It enables them to grow intellectually, raise their cultural awareness and build bridges between cultures. Türker goes on to say that the student who learns through the use of literature can feel "the power and possibility of contributing positively to a larger world than just his own" and that literature is an "ideal vehicle for illustrating language use and for introducing cultural assumptions" (Türker, 2014:304). Each literary text mentioned can provide the teacher with numerous language learning activities as previously mentioned. All the tasks and exercises based on a literary text can provide the students with invaluable practice and help them master different language skills, but they can also go beyond the classroom and help the students relate to different cultures and learn about and from them.

The courses that use the book Stein på stein and include its literary excerpts can be considered successful as shown by the statistically processed data obtained by the learners. The students reported an overall positive impact of the literary texts on their language learning process. They felt closer to the people of the target language and more inclined to further immerse themselves in the culture and explore it outside the classroom. They were given the chance to express their ideas in Norwegian, see how the idiomatic expressions are used, be creative and critical, open new horizons of possibilities and much more. In the end, one can conclude that using literature in language teaching can be beneficial for the students and their learning process because it not only gives them the opportunity to practice and perfect their language skills but it also builds up intercultural competence giving them insight into the culture of the society whose language they are learning.

\section{REFERENCES}

Babaee, Ruzbeh, and Wan Roselezam Bt Wan Yahya. "Significance of Literature in Foreign Language Teaching." International Education Studies 7, no. 4 (2014): 80-85.

Bagchi, Alaknanda. "Conflicting Nationalisms: The Voice of the Subaltern in Mahasweta Devi's Bashai Tudu." Tulsa Studies in Women's Literature 15, no. 1 (1996): 41-50.

Bobkina, Jelena, and Elena Dominguez. "The use of literature and literary texts in the EFL classroom; between consensus and controversy." International Journal of Applied Linguistics and English Literature 3, no. 2 (2014): 248-260.

Bottino, Olga. "Literature and language teaching." Actas do 4 (1999): 211-214.

Brown, Jean E. "Learning through Listening Strategies for Literature." Language Arts Journal of Michigan 17, no. 2 (2001): 4.

Brumfit, Christopher, and Ronald Carter, eds. Literature and language teaching. Vol. 289. Oxford: Oxford university press, (1986).

Carter, Ronald, and N. Michael. "Long. M. (1991). Teaching Literature." Harlow: Longman. Celce Murcia, $M$ (2003): 3-9.

Cook, Guy. Applied linguistics. Oxford University Press, (2003).

Collie, Joanne, and Stephen Slater. Literature in the language classroom: A resource book of ideas and activities. Ernst Klett Sprachen, (1987).

Ellingsen, Elisabeth, and Kirsti MacDonald. Stein på stein. Cappelen, (2005).

Hişmanoğlu, Murat. "Teaching English through literature." Dil ve Dilbilimi Çalışmaları Dergisi 1, no. 1 (2005): 53-66.

Keshavarzi, Abdollah. "Use of literature in teaching English." Procedia-Social and Behavioral Sciences 46 (2012): 554-559. 
Kitao, Kenji. "Teaching Culture in Foreign Language Instruction in the United States." Doshisha Studies in English 52, no. 53 (1991): 285-306.

Kelner, Lenore Blank. The Creative Classroom: A Guide for Using Creative Drama in the Classroom, PreK-6. Heinemann, 361 Hanover St., Portsmouth, NH 03801-3912., (1993).

Padurean, Alina Nicoleta. "Approaches to teaching literature in EFL classrooms." Journal of Romanian Literary Studies 06 (2015): 195-200.

Phat, Cao Hong. "The Implementation of Literature in Teaching Speaking for Advanced Students." In 3rd International Conference on Foreign Language Learning and Teaching, Retrieved from: http://www. fllt2013. org. 2013.

Povey, John F. "Literature in TESL programs: The language and the culture." TESOL quarterly 1, no. 2 (1967): 40-46.

Ritlyavá, A. "Creative use of literature in language teaching." Tvorivost'v škole-škola tvorivosti 2 (2014).

Shazu, Rafiul Islam. "Use of literature in language teaching and learning: A critical assessment." Journal of Education and Practice 5, no. 7 (2014): 29-35.

TÜRKER, Faruk. "Using literature in language teaching." Hacettepe Üniversitesi Ĕgitim Fakültesi Dergisi 6, no. 6 (1991).

Ur, Penny. A course in language teaching. Ernst Klett Sprachen, (2008). 